\title{
Pengaruh Efektivitas Media Promosi Kesehatan Leaflet dengan Video TOSS TB Terhadap Tingkat Pengetahuan dan Sikap Masyarakat di Wilayah Kerja Puskesmas Andalas
}

\author{
Karynina Danti Putri ${ }^{1}$, Rima Semiarty ${ }^{2}$, Linosefa ${ }^{3}$ \\ ${ }^{1}$ Profesi Dokter Fakultas Kedokteran Universitas Andalas \\ ${ }^{2}$ Bagian IImu Kesehatan Masyarakat Fakultas Kedokteran Universitas Andalas \\ ${ }^{3}$ Bagian Mikrobiologi Klinik Fakultas Kedokteran Universitas Andalas
}

\begin{abstract}
A B S T R A C T
Latar Belakang. Promosi kesehatan merupakan proses memandirikan masyarakat untuk merubah perilaku kesehatannya. leaflet dan video dipilih sebagai media promosi kesehatan karena bernilai praktis dalam penyaluran informasi.

Objektif. Penelitian ini bertujuan untuk mengetahui pengaruh efektivitas media promosi kesehatan leaflet dengan video TOSS TB terhadap tingkat pengetahuan dan sikap masyarakat di wilayah kerja Puskesmas Andalas.
\end{abstract}

Metode. Penelitian ini merupakan penelitian quasy experimental. Terdiri dari dua kelompok penelitian (kelompok leaflet dan video) dengan jumlah sampel 144. Analisis data dengan analisis univariat dan uji Mann Whitney serta uji Kruskal Wallis untuk analisis bivariat dengan kemaknaan statistik $p<0,05$.

Hasil. Hasil analisis univariat menunjukkan masyarakat sebelum diberi intervensi memiliki tingkat pengetahuan baik dan sikap positif sebesar $85,42 \%$ dan $68,75 \%$. Setelah diberikan intervensi menjadi $92,36 \%$ dan $74,30 \%$. Hasil analisis bivariat menunjukkan terdapat perubahan signifikan sebelum dengan sesudah diberikan intervensi dengan perubahan rata-rata pengetahuan pada kelompok leaflet dan video adalah 0,588 , 0,710 , dengan $p$ value $=0,000$. Serta pada sikap adalah 0,289 , 0,477 , dengan $\mathrm{p}$ value $=0,000$.

Kesimpulan. Media leaflet dan video berpengaruh dalam meningkatkan pengetahuan dan sikap TOSS TB masyarakat dimana media video merupakan media yang paling efektif.

Kata Kunci: leaflet, promosi kesehatan, TOSS TB, video

Background. Health promotion is a process of helping people to change their health behavior. The leaflet and videos were chosen as a health promotion media because they have a practical value in distributing information.

Objective. This study aims to determine the differences in the effectiveness of leaflet with video toss tb as health promotion media on knowledge and attitude of community in andalas puskesmas working areas.

Methods. This research is a quasi-experimental study. This study consisted of two research groups, leaflet and video with a total sample of 144. Data analysis using univariate analysis and the Mann Whitney test and the Kruskal Wallis test for bivariate analysis with statistical significance was determined if the $p$ value $<0.05$.

Results. The results of univariate analysis showed that the community before being given an intervention had a good level of knowledge and a positive attitude of $85.42 \%$ and 68.75\%. After being given the intervention it became $92.36 \%$ and $74.30 \%$. The results of the bivariate analysis showed that there were significant changes before and after the intervention was given. The results of changes in the average knowledge in the leaflet and video groups are 0.588,0.710, with $p$ value $=0,000$. And the attitude is $0.289,0.477,0.102$, with $p$ value $=0.000$.

Conclution. the leaflet and video influence to change $a$ knowledge and attitude of TOSS TB in the community and the video is the most effective media.

Keywords: health promotion, leaflet, TOSS TB, Video

\section{Apa yang sudah diketahui tentang topik ini?}

Media Promosi Kesehatan seperti leaflet dan video dapat memengaruhi tingkat pengetahuan dan sikap masyarakat.

\section{Apa yang ditambahkan pada studi ini?}

Media video merupakan media yang paling efektif dalam meningkatkan Pengetahuan dan Sikap Masyarakat mengenai TOSS TB.

\section{CORRESPONDING AUTHOR}

Phone: +628126608040

E-mail: rimamenkher@yahoo.com

\section{ARTICLE INFORMATION}

Received: July $30^{\text {th }}, 2020$

Revised: March $15^{\text {th }}, 2021$

Available online: May $27^{\text {th }}, 2021$ 


\section{Pendahuluan}

Promosi kesehatan adalah suatu proses untuk memandirikan dan memampukan masyarakat agar mampu meningkatkan tingkat kesehatannya, baik itu kesehatan pribadi maupun kesehatan di lingkungan. ${ }^{1}$ Dalam memengaruhi perilaku kesehatan masyarakat, perlu beberapa usaha dalam melakukan promosi kesehatan. Dimana dalam penyampaian infomasi dari promosi kesehatan tersebut harus efektif, dapat merangsang pikiran, perasaan, dan kemauan seseorang sehingga dapat mendorong terjadinya proses belajar. Cara penyampaian informasi kesehatan yang dianggap efektif itu salah satunya adalah melalui media promosi kesehatan. ${ }^{3}$

Media promosi kesehatan merupakan suatu sarana dan upaya untuk menampilkan informasi atau pesan yang ingin disampaikan oleh komunikator dengan sasaran berupa peningkatan pengetahuan untuk mengubah perilaku kesehatan yang lebih baik. ${ }^{4}$ Media yang biasa digunakan dalam promosi kesehatan dapat berupa media visual, audio, maupun audio visual. ${ }^{2}$

Media leaflet dipilih sebagai media promosi kesehatan karena memiliki nilai praktis yang mudah untuk dibawa kemana saja, misalnya dapat dimasukkan ke dalam dompet, selain itu juga dapat dibaca kapan saja jika mereka ingin membaca kembali. ${ }^{6}$ Sedangkan media video dipilih sebagai media promosi kesehatan karena video lebih efisiensi dalam penyaluran informasi secara lebih menyeluruh, terutama dengan adanya media sosial di smartphone video dapat dibagikan dan dapat ditonton oleh banyak orang. ${ }^{7,8}$

Berdasarkan penelitian yang dilakukan oleh Surya tahun 2015 mengenai Pengaruh Media Poster Kalender dan leaflet Terhadap Pengetahuan dan Sikap Pasien TB Paru dalam Menjaga Kelangsungan Pengobatan Penyakit TB Paru di Puskesmas Terjun Kota Medan Tahun 2015 diapatkan bahwa dari kedua media tersebut sama-sama meningkatkan pengetahuan dan sikap. $^{37}$ Penelitian lain yang dilakukan oleh Ketrina tahun 2017 mengenai Efektifitas Metode Ceramah Dan leaflet Dalam Upaya Meningkatkan Perilaku Penderita Tuberkulosis Paru Tentang Pencegahan Penularan Penyakit TB Paru Di Puskesmas Tuminting Kota Manado didapatkan bahwa media leaflet yang paling meningkatkan perilaku terhadap pencegahan penularan penyakit TB paru. ${ }^{38}$
Tuberkulosis (TB) merupakan suatu penyakit menular yang menjadi salah satu dari 10 penyebab kematian di dunia pada tahun 2018. Data WHO 2018 memperkirakan secara global terdapat 10 juta orang jatuh sakit dengan angka kematian sebanyak 1,5 juta orang meninggal karena TB. Indonesia menempati peringkat kedua negara dengan insiden TB terbanyak. ${ }^{9}$

Berdasarkan Laporan Dinas Kesehatan Sumatera Barat tahun 2018 untuk insiden seluruh kejadian TB adalah 131,65 per 100.000 penduduk (6852 kasus). ${ }^{10}$ Pada tahun 2018, penemuan kasus TB di Kota Padang diperkirakan keseluruhan kejadian TB paru di Kota Padang adalah sekitar 251,09 per 100.000 penduduk (2358 kasus). Wilayah kerja Puskesmas Andalas merupakan Puskesmas dengan insiden TB terbanyak di Kota Padang. ${ }^{11}$ Selain itu wilayah kerja Puskesmas Andalas yang berada di Kecamatan Padang Timur merupakan wilayah dengan kepadatan penduduk paling padat di Kota Padang yaitu sebesar 10.345,12/km2.12 Sehingga risiko untuk terjadinya penyakit menular salah satunya seperti TB sangat tinggi.

Dari data tersebut dapat diketahui bahwa TB merupakan salah satu penyakit menular yang masih menjadi masalah bagi kesehatan masyarakat. ${ }^{13}$ Perlu dilakukannya upaya preventif dan promotif terhadap TB sebab angka morbiditas dan mortalitasnya tinggi. Menyikapi hal tersebut pemerintah melalui Peraturan Menteri Kesehatan Republik Indonesia Pasal 1 Nomor 67 Tahun 2016 Tentang Penanggulangan Tuberkulosis. Pengendalian TB tersebut diwujudkan dalam suatu program yang disebut dengan Temukan dan Obati Sampai Sembuh Tuberkulosis (TOSS TB). ${ }^{14}$ Program ini bertujuan untuk mewujudkan target penanggulangan TB nasional yaitu eliminasi pada tahun 2035 dan Indonesia bebas TB pada tahun $2050 .{ }^{15}$

Berdasarkan latar belakang diatas, penelitian ini dilakukan dengan tujuan untuk mengetahui pengaruh efektivitas media promosi kesehatan leaflet dengan video terhadap tingkat pengetahuan dan sikap masyarakat di wilayah kerja Puskesmas Andalas.

\section{Metode}

Jenis penelitian yang dilakukan dalam penelitian ini adalah quasy experimental. Pada penelitian ini akan dilakukan pre test, perlakuan, 
dan post test. Ditujukan kepada dua kelompok subjek dengan tingkat kelas yang sama (homogen) tetapi dengan perlakuan berbeda yaitu kelompok leaflet dengan video.

Populasi penelitian ini adalah warga yang berada di wilayah kerja Puskesmas Andalas yang terdiri dari 10 kelurahan dengan jumlah populasi sebanyak 85.937 orang. Dalam penelitian ini didapatkan total sampel keseluruhan untuk tiga kelompok sebanyak 144 orang. Pengambilan sampel untuk penelitian ini dengan menggunakan teknik Probability Sampling dengan metode proportionate stratified random sampling.

Analisis data dilakukan secara univariat dan bivariat. Analisis univariat dilakukan untuk menggambarkan karakteristik responden dan distribusi skor pengetahuan dan sikap dari masyarakat sebelum dan sesudah diberikan promosi tentang TOSS TB pada kelompok leaflet dan video. Analisis bivariat berfungsi untuk menguji hipotesis. Uji Mann Whitney dilakukan untuk mengetahui apakah terdapat pengaruh pengetahuan sebelum dengan sesudah pada setiap kelompok yang berhubungan. Uji Kruskal Wallis dilakukan untuk mengetahui selisih pengaruh perubahan pada lebih dari dua kelompok sampel yang tidak berhubungan.

\section{Hasil}

Penelitian ini bertujuan untuk mengetahui pengaruh efektivitas media promosi kesehatan leaflet dengan video terhadap tingkat pengetahuan dan sikap masyarakat di wilayah kerja Puskesmas Andalas. Penelitian dilakukan di 10 kelurahan di wilayah kerja puskesmas Andalas pada bulan Februari-Juli 2020.

\section{Distribusi Frekuensi Tingkat Pengetahuan TOSS TB Masyarakat Sebelum Menggunakan Media leaflet dan Media Video}

Pada penelitian ini didapatkan bahwa distribusi frekuensi pre test pengetahuan TOSS TB pada masyarakat sebagian besar memiliki tingkat pengetahuan yang baik pada kelompok leaflet dan video yaitu sebanyak 39 orang $(81,3 \%)$, dan 43 orang $(89,6 \%)$.
Tabel 1. Distribusi Frekuensi Pre test Pengetahuan TOSS TB Masyarakat Pada Kelompok leaflet

\begin{tabular}{lcc}
\hline \multicolumn{1}{c}{ Variabel } & \multicolumn{2}{c}{ Pre Test } \\
\cline { 2 - 3 } & F & \% \\
\hline Tingkat Pengetahuan & & \\
TOSS TB & & \\
$\quad$ Baik (76-100\%) & 39 & 81,3 \\
Cukup (60-75\%) & 9 & 18,8 \\
$\quad$ Kurang $(<60 \%)$ & 0 & 0 \\
Total & 48 & 100 \\
\hline
\end{tabular}

Tabel 2. Distribusi Frekuensi Pre test Pengetahuan TOSS TB Masyarakat Pada Kelompok Video

\begin{tabular}{lcc}
\hline \multicolumn{1}{c}{ Variabel } & \multicolumn{2}{c}{ Pre Test } \\
\cline { 2 - 3 } & $\mathbf{F}$ & $\mathbf{\%}$ \\
\hline Tingkat Pengetahuan & & \\
TOSS TB & & \\
$\quad$ Baik (76-100\%) & 43 & 89,6 \\
Cukup (60-75\%) & 3 & 6,3 \\
$\quad$ Kurang (<60\%) & 2 & 4,2 \\
Total & 48 & 100 \\
\hline
\end{tabular}

\section{Distribusi Frekuensi Tingkat Sikap TOSS TB Masyarakat Sebelum Menggunakan Media leaflet dan Media Video}

Pada penelitian ini didapatkan bahwa distribusi frekuensi pre test sikap TOSS TB pada masyarakat sebagian besar memiliki sikap yang positif baik pada kelompok leaflet dan video yaitu sebanyak 32 orang $(66,7 \%)$, dan 36 orang (75\%).

Tabel 3. Distribusi Frekuensi Pre test Sikap TOSS TB Masyarakat Pada Kelompok leaflet

\begin{tabular}{|c|c|c|}
\hline \multirow[t]{2}{*}{ Variabel } & \multicolumn{2}{|c|}{ Pre Test } \\
\hline & $\mathbf{F}$ & $\%$ \\
\hline Tingkat Sikap TOSS TB & & \\
\hline $\begin{array}{l}\text { Positif (skor } \quad \mathrm{T} \geq \\
\text { mean) }\end{array}$ & 32 & 66,7 \\
\hline $\begin{array}{l}\text { Negatif } \\
\mathrm{T}<\text { mean) }\end{array}$ & 16 & 33,3 \\
\hline Total & 48 & 100 \\
\hline
\end{tabular}

Tabel 4. Distribusi Frekuensi Pre test Sikap TOSS TB Masyarakat Pada Kelompok Video

\begin{tabular}{|c|c|c|}
\hline \multirow[t]{2}{*}{ Variabel } & \multicolumn{2}{|c|}{ Pre Test } \\
\hline & $\mathbf{F}$ & $\%$ \\
\hline Tingkat Sikap TOSS TB & & \\
\hline $\begin{array}{l}\text { Positif (skor } \quad \mathrm{T} \geq \\
\text { mean) }\end{array}$ & 36 & 75 \\
\hline $\begin{array}{l}\text { Negatif } \\
\mathrm{T}<\text { mean) }\end{array}$ & 12 & 25 \\
\hline Total & 48 & 100 \\
\hline
\end{tabular}


3. Distribusi Frekuensi Tingkat Pengetahuan TOSS TB Masyarakat Sesudah Menggunakan Media leaflet dan Media Video

Pada penelitian ini didapatkan bahwa distribusi frekuensi post test pengetahuan TOSS TB pada masyarakat sebagian besar memiliki tingkat pengetahuan yang baik pada kelompok leaflet dan video yaitu sebanyak 44 orang (91,7\%), dan 47 orang (97,9\%).

Tabel 5. Distribusi Frekuensi Post test Pengetahuan TOSS TB Masyarakat Pada Kelompok leaflet

\begin{tabular}{lcc}
\hline \multicolumn{1}{c}{ Variabel } & \multicolumn{2}{c}{ Pre Test } \\
\cline { 2 - 3 } & F & \% \\
\hline Tingkat Pengetahuan & & \\
TOSS TB & & \\
$\quad$ Baik $(76-100 \%)$ & 44 & 91,7 \\
Cukup (60-75\%) & 4 & 8,3 \\
$\quad$ Kurang (<60\%) & 0 & 0 \\
Total & 48 & 100 \\
\hline
\end{tabular}

Tabel 6. Distribusi Frekuensi Post test Pengetahuan TOSS TB Masyarakat Pada Kelompok Video

\begin{tabular}{lcc}
\hline \multicolumn{1}{c}{ Variabel } & \multicolumn{2}{c}{ Pre Test } \\
\cline { 2 - 3 } & $\mathbf{F}$ & $\%$ \\
\hline Tingkat Pengetahuan & & \\
TOSS TB & & \\
Baik $(76-100 \%)$ & 47 & 97,9 \\
Cukup (60-75\%) & 1 & 2,1 \\
Kurang (<60\%) & 0 & 0 \\
Total & 48 & 100 \\
\hline
\end{tabular}

\section{Distribusi Frekuensi Tingkat Sikap TOSS TB} Masyarakat Sesudah Menggunakan Media leaflet dan Media Video

Pada penelitian ini didapatkan bahwa distribusi frekuensi post test sikap TOSS TB pada masyarakat sebagian besar memiliki sikap yang positif pada kelompok leaflet dan video yaitu sebanyak 34 orang $(70,8 \%)$, dan 43 orang $(89,6 \%)$.

Tabel 7. Distribusi Frekuensi Post test Sikap TOSS TB Masyarakat Pada Kelompok leaflet

\begin{tabular}{|c|c|c|}
\hline \multirow{2}{*}{ Variabel } & \multicolumn{2}{|c|}{ Pre Test } \\
\hline & $\mathbf{F}$ & $\%$ \\
\hline Tingkat Sikap TOSS TB & & \\
\hline $\begin{array}{l}\text { Positif (skor } \quad \mathrm{T} \geq \\
\text { mean) }\end{array}$ & 34 & 70,8 \\
\hline $\begin{array}{l}\text { Negatif } \\
\mathrm{T}<\text { mean) }\end{array}$ & 14 & 29,2 \\
\hline Total & 48 & 100 \\
\hline
\end{tabular}

Tabel 8. Distribusi Frekuensi Post test Sikap TOSS TB Masyarakat Pada Kelompok Video

\begin{tabular}{|c|c|c|}
\hline \multirow[t]{2}{*}{ Variabel } & \multicolumn{2}{|c|}{ Pre Test } \\
\hline & $\mathbf{F}$ & $\%$ \\
\hline Tingkat Sikap TOSS TB & & \\
\hline $\begin{array}{l}\text { Positif (skor } \quad \mathrm{T} \geq \\
\text { mean) }\end{array}$ & 43 & 89,6 \\
\hline $\begin{array}{l}\text { Negatif } \\
\mathrm{T}<\text { mean) }\end{array}$ & 5 & 10,4 \\
\hline Total & 48 & 100 \\
\hline
\end{tabular}

\section{Pengaruh Pengetahuan TOSS TB} Masyarakat Sebelum dan Sesudah Menggunakan Media leaflet

Pada penelitian ini didapatkan hasil analisis bivariat menggunakan uji Mann Whitney didapatkan ( $p$ value $=0,001)$ ada pengaruhyang signifikan pengetahuan TOSS TB masyarakat antara sebelum dan sesudah diberikan dengan leaflet.

Tabel 9. Hasil Uji pengaruh Pengetahuan TOSS TB Masyarakat Sebelum dan Sesudah Menggnakan Media leaflet

\begin{tabular}{cccc}
\hline Kelompok & $\boldsymbol{\Delta M e a n}$ & SD & $\boldsymbol{p}$ value \\
\hline Pre test & 8,484 & 0,845 & 0,001 \\
Post test & 9,072 & 0,784 & \\
\hline
\end{tabular}

6. Pengaruh Pengetahuan TOSS TB Masyarakat Sebelum dan Sesudah Menggunakan Media Video

Pada penelitian ini didapatkan hasil analisis bivariat menggunakan uji Mann Whitney didapatkan ( $p$ value $=0,002$ ) ada pengaruh yang signifikan pengetahuan TOSS TB masyarakat antara sebelum dan sesudah diberikan dengan video.

Tabel 10. Hasil Uji pengaruh Pengetahuan TOSS TB Masyarakat Sebelum dan Sesudah Menggnakan Media Video

\begin{tabular}{cccc}
\hline Kelompok & $\boldsymbol{\Delta M e a n}$ & SD & p value \\
\hline Pre test & 8,655 & 1,170 & 0,002 \\
Post test & 9,356 & 0,457 & \\
\hline
\end{tabular}

\section{Pengaruh Sikap TOSS TB Masyarakat} Sebelum dan Sesudah Menggunakan Media leaflet

Pada penelitian ini didapatkan hasil analisis bivariat menggunakan uji Mann Whitney didapatkan ( $p$ value $=0,004)$ ada pengaruh yang signifikan sikap TOSS TB masyarakat antara sebelum dan sesudah diberikan intervensi dengan leaflet. 
Tabel 11. Hasil Uji pengaruh Sikap TOSS TB Masyarakat Sebelum dan Sesudah Menggnakan Media leaflet

\begin{tabular}{cccc}
\hline Kelompok & DMean & SD & p value \\
\hline Pre test & 8,423 & 0,453 & 0,004 \\
Post test & 8,712 & 0,507 & \\
\hline
\end{tabular}

8. Pengaruh Sikap TOSS TB Masyarakat Sebelum dan Sesudah Menggunakan Media Video

Pada penelitian ini didapatkan hasil analisis bivariat menggunakan uji Mann Whitney didapatkan ( $p$ value $=0,001$ ) ada pengaruh yang signifikan sikap TOSS TB masyarakat antara sebelum dan sesudah diberikan intervensi dengan video.

Tabel 12. Hasil Uji pengaruh Sikap TOSS TB Masyarakat Sebelum dan Sesudah Menggnakan Media Video

\begin{tabular}{cccc}
\hline Kelompok & $\boldsymbol{\Delta M e a n}$ & SD & p value \\
\hline Pre test & 8,759 & 0,688 & 0,001 \\
Post test & 9,230 & 0,503 & \\
\hline
\end{tabular}

\section{Pengaruh Rata-Rata Tingkat Pengetahuan TOSS TB Masyarakat Antara Kelompok leaflet dan Video}

Pada penelitian ini didapatkan perubahan rata-rata tingkat pengetahuan pre test dengan post test pada kelompok leaflet adalah 0,588 dengan standar deviasi 0,344 . Perubahan rata-rata tingkat pengetahuan pre test dengan post test pada kelompok video adalah 0,710 dengan standar deviasi 0,345 . Terdapat pengaruh yang signifikan pengetahuan TOSS TB masyarakat antara kelompok leaflet dan video dengan kelompok video yang memiliki nilai paling tinggi.

Tabel 13. Hasil Uji Selisih Rata-Rata Tingkat Pengetahuan Pre test dan Post test Antara Kelompok leaflet dan Video

\begin{tabular}{cccc}
\hline Kelompok & $\boldsymbol{\Delta M e a n}$ & SD & $\boldsymbol{p}$ value \\
\hline leaflet & 0,588 & 0,344 & 0,000 \\
Video & 0,710 & 0,345 & \\
\hline
\end{tabular}

Tabel 14. Hasil Uji Selisih Pengetahuan TOSS TB Masyarakat Antara Kelompok leaflet dan Video

\begin{tabular}{ccc}
\hline Kelompok & Mean range & $\boldsymbol{p}$ value \\
\hline leaflet vs Video & $0,171-0,284$ & 0,000 \\
\hline
\end{tabular}

\section{Pengaruh Rata-Rata Sikap TOSS TB Masyarakat Antara Kelompok leaflet dan Video}

Pada penelitian ini didapatkan perubahan rata-rata tingkat sikap pre test dengan post test pada kelompok leaflet adalah 0,289 dengan standar deviasi 0,466. Perubahan rata-rata tingkat sikap pre test dengan post test pada kelompok video adalah 0,477 dengan standar deviasi 0,384. Terdapat pengaruh yang signifikan sikap TOSS TB masyarakat antara kelompok leaflet dan video dengan kelompok video yang memiliki nilai paling tinggi.

Tabel 15. Hasil Uji Selisih Rata-Rata Sikap Pre test dan Post test Antara Kelompok leaflet dan Video

\begin{tabular}{cccc}
\hline Kelompok & $\boldsymbol{\Delta M e a n}$ & SD & $\boldsymbol{p}$ value \\
\hline leaflet & 0,289 & 0,466 & 0,000 \\
Video & 0,477 & 0,384 & \\
\hline
\end{tabular}

Tabel 16. Hasil Uji Selisih Sikap TOSS TB Masyarakat Antara Kelompok leaflet dan Video

\begin{tabular}{ccc}
\hline Kelompok & Mean range & p value \\
\hline leaflet vs Video & $0,336-0,518$ & 0,000 \\
\hline
\end{tabular}

\section{Pembahasan}

1. Distribusi Frekuensi Tingkat Pengetahuan TOSS TB Masyarakat Sebelum Menggunakan Media leaflet dan Media Video

Dari hasil penelitian yang telah dilakukan, didapatkan bahwa tingkat pengetahuan TOSS TB Masyarakat di Wilayah Kerja Puskesmas Andalas sebelum diberikan intervensi sebagian besar sudah berada pada kategori baik. Hasil pada penelitian ini sejalan dengan penelitian yang dilakukan oleh Sumiyati, dkk (2018) bahwa sebagian besar masyarakat memiliki tingkat pengetahuan yang baik mengenai penyakit Tuberkulosis sebelum dilakukan intervensi yaitu dengan persentase $73,3 \% .16$

Terdapatnya pengaruh tingkat pengetahuan seseorang dapat dipengaruhi oleh banyak faktor. ${ }^{17}$ Hal tersebut dapat dilihat dari hasil penelitian yang menunjukkan bahwa terdapatnya pengaruh pengetahuan antara satu masyarakat dengan masyarakat lainnya yang berada di wilayah berbeda. Faktor yang dapat memengaruhi pengaruh tingkat pengetahuan seseorang adalah pendidikan, paparan informasi atau media massa, sosial, budaya, lingkungan, ekonomi, pengalaman, dan usia. 


\section{Distribusi Frekuensi Tingkat Sikap TOSS TB Masyarakat Sebelum Menggunakan Media leaflet dan Media Video}

Berdasarkan hasil penelitian didapatkan bahwa sebagian besar masyarakat menunjukkan sikap yang positif terhadap TOSS TB sebelum diberi intervensi. Hasil penelitian ini relevan dengan penelitian yang dilakukan oleh Heda Melinda, dkk (2018) didapatkan sebanyak 69,2\% masyarakat bersikap positif mengenai penyakit Tuberkulosis sebelum diberikan intervensi. ${ }^{18}$

Sikap merupakan bentuk dari ketersediaan seseorang dalam menerima stimulus yang diberikan serta adanya pengalaman. Setelah seseorang tersebut mendapatkan pengalaman, mereka akan mulai menanggapi sehingga mampu memberi jawaban atau respon dari sebuah tanggapan yang diberikan. ${ }^{19}$ Pengetahuan juga dapat memengaruhi sikap seseorang, terutama terhadap sikap TOSS TB. Pernyataan ini didukung oleh penelitian yang dilakukan oleh Siti, dkk (2009) yang menyatakan bahwa terdapat hubungan antara pengetahuan dan sikap mengenai pencegahan penularan TBC. ${ }^{20}$

\section{Distribusi Frekuensi Tingkat Pengetahuan}

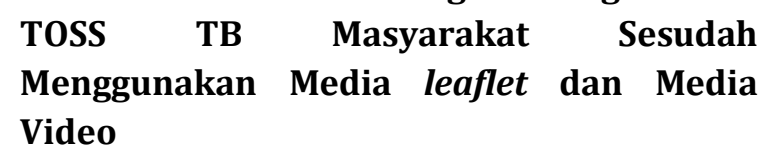

Berdasarkan hasil penelitian didapatkan bahwa tingkat pengetahuan setelah diberi intervensi berupa media leaflet dan video sebagian besar memiliki tingkat pengetahuan baik dengan mengalami peningkatan dari sebelumnya ketika belum diberi intervensi. Hasil tersebut sejalan dengan penelitian yang dilakukan oleh Arief (2013) bahwa terdapatnya peningkatan tingkatan pengetahuan setelah diberi intervensi berupa leaflet dan video. ${ }^{21}$

Pemberian informasi yang dilakukan baik secara formal maupun non formal dapat memengaruhi pengetahuan seseorang. ${ }^{22}$ Informasi yang didapatkan dari media promosi kesehatan merupakan suatu bentuk pengalaman yang dapat membuat seseorang mengetahui sebuah informasi.23 Pada penelitian ini media yang digunakan adalah leaflet dan video. Kedua media tersebut memiliki kelebihan dan kekurangannya masing-masing dalam menyalurkan informasi.

\section{Distribusi Frekuensi Tingkat Sikap TOSS TB Masyarakat Sesudah Menggunakan Media leaflet dan Media Video}

Berdasarkan hasil penelitian didapatkan bahwa sikap setelah diberi intervensi berupa leaflet dan video sebagian besar memiliki sikap yang positif dengan mengalami peningkatan dari sebelumnya ketika belum diberi intervensi. Pada hasil penelitian yang didapatkan tersebut sejalan dengan penelitian yang dilakukan oleh Dina (2018) bahwa terdapatnya perubahan nilai sikap setelah diberikan intervensi dengan menggunakan leaflet. $^{24}$

Sikap merupakan suatu bentuk kesiapan dan ketersediaan dalam merespons suatu objek. Terdapat faktor yang memengaruhi sikap seseorang, selain adanya pengalaman pribadi, kebudayaan, dan pendidikan, media massa juga berperan dalam melancarkan tercapainya suatu informasi. Pada penelitian ini digunakan media leaflet dan video yang bertujuan untuk memengaruhi sikap masyarakat. Media tersebut nantinya akan membentuk sugesti sehingga terciptanya opini-opini yang akan memengaruhi sikap seseorang. ${ }^{25}$

\section{Pengaruh Pengetahuan TOSS TB Masyarakat Sebelum dan Sesudah Menggunakan Media leaflet}

Berdasarkan hasil penelitian didapatkan bahwa nilai rata-rata tingkat pengetahuan TOSS TB masyarakat sebelum diberikan intervensi dengan leaflet adalah 8,484. Setelah diberi intervensi terjadi kenaikan sebesar 9,072. Hasil uji statistik dengan menggunakan Uji Mann Whitney didapatkan $\mathrm{p}$ value $=0,001(\mathrm{p}$ value $<0,05)$, adanya pengaruh yang signifikan pengetahuan TOSS TB masyarakat antara sebelum dan sesudah intervensi dengan leaflet. Hasil ini sesuai dengan hasil penelitian yang dilakukan oleh Nur Syamsiyah (2013) bahwa media leaflet dapat memengaruhi tingkat pengetahuan. ${ }^{26}$

Pemberian informasi baik secara formal maupun tidak formal dapat memengaruhi tingkat pengetahuan seseorang. Penyuluhan kesehatan salah satu faktor yang berperan dalam peningkatan pengetahuan dengan terjadinya proses penyampaian informasi. ${ }^{19}$ Dari pengetahuan ini akan terbentuk suatu tindakan hingga terjadinya perubahan perilaku. ${ }^{23}$ 


\section{Pengaruh Pengetahuan TOSS TB Masyarakat Sebelum dan Sesudah Menggunakan Media Video}

Berdasarkan hasil penelitian didapatkan bahwa nilai rata-rata tingkat pengetahuan TOSS TB masyarakat sebelum diberikan intervensi dengan video adalah 8,655. Setelah diberi intervensi terjadi kenaikan sebesar 9. Hasil Uji Mann Whitney didapatkan nilai $\mathrm{p}$ value $=0,002(\mathrm{p}$ value $<0,05$ ), adanya pengaruh yang signifikan pengetahuan TOSS TB masyarakat antara sebelum dan sesudah intervensi dengan video. Hasil penelitian ini sejalan dengan hasil penelitian yang dilakukan oleh Sekar (2019) bahwa adanya peningkatan yang signifikan pada pengetahuan setelah diberikan pendidikan kesehatan dengan menggunakan video. ${ }^{27}$

Promosi kesehatan merupakan bentuk upaya dalam memperbaiki tingkat kesehatan seseorang. ${ }^{2}$ Banyak sekali metode yang digunakan dalam mempromosikan kesehatan agar tersampainya informasi kesehatan kepada masyarakat. Video dipilih sebagai media promosi kesehatan karena video merupakan suatu elemen dari multimedia yang paling dinamis dan realistis. Sehingga penggunaan video sebagai media promosi kesehatan dapat memengaruhi perasaan dan emosi secara lebih nyata. ${ }^{28}$

\section{Pengaruh Sikap TOSS TB Masyarakat Sebelum dan Sesudah Menggunakan Media leaflet}

Berdasarkan hasil penelitian didapatkan bahwa nilai rata-rata tingkat sikap TOSS TB masyarakat sebelum diberikan intervensi dengan leaflet adalah 8,423. Setelah diberi intervensi terjadi kenaikan sebesar 8,712. Hasil Uji Mann Whitney didapatkan nilai $\mathrm{p}$ value $=0,004$ ( $\mathrm{p}$ value $<0,05$ ), adanya pengaruh yang signifikan sikap TOSS TB masyarakat antara sebelum dan setelah intervensi dengan menggunakan leaflet. Hasil penelitian ini sejalan dengan penelitian yang dilakukan oleh Surya (2015) bahwa terdapatnya peningkatkan yang signifikan sikap setelah diberikan penyuluhan dengan menggunakan leaflet. ${ }^{31}$

Sikap TOSS TB memiliki makna penting dalam membuat persepsi seseorang untuk menentukan bahwa seseorang tersebut akan memilih untuk bersikap positif atau pun negatif. Dalam melancarkan tersampaikannya sebuah informasi kepada kelompok sasaran, diperlukan media massa yang mampu memberikan sugesti yang akan memengaruhi sikap seseorang menjadi positif ataupun negatif. ${ }^{25}$ Pada penelitian ini digunakan leaflet sebagai salah satu media yang dapat memengaruhi sikap seseorang.

\section{Pengaruh Sikap TOSS TB Masyarakat Sebelum dan Sesudah Menggunakan Media Video}

Berdasarkan hasil penelitiandidapatkan bahwa nilai rata-rata tingkat sikap TOSS TB masyarakat sebelum diberikan intervensi dengan video adalah 8,759. Setelah diberi intervensi terjadi kenaikan sebesar 9,230. Hasil Uji Mann Whitney didapatkan nilai $\mathrm{p}$ value $=0,001(\mathrm{p}$ value $<0,05)$, adanya pengaruh yang signifikan sikap TOSS TB masyarakat antara sebelum dan setelah intervensi dengan menggunakan video. Hal ini sejalan dengan penelitian yang dilakukan oleh Yuli, dkk (2018) bahwa adanya pengaruh yang bermakna antara sikap sebelum dengan sesudah edukasi pada kelompok intervensi berupa pemberian video. ${ }^{32}$

Sikap masyarakat yang berkaitan dengan TOSS TB masih beragam. Masih ada beberapa masyarakat yang kurang peduli. Salah satu contohnya adalah masyarakat yang tidak peduli ketika terdapat gejala seperti batuk yang lebih dari tiga minggu dan menganggap itu bukan penyakit yang serius sehingga tidak segera melakukan pengobatan dan hanya mengkonsumsi obat di warung. ${ }^{33}$ Maka dari itu promosi kesehatan penting dalam merubah sikap seseorang. Dengan menggunakan media promosi kesehatan yang efektif salah satunya dengan menggunakan video, dengan harapan mampu merubah sikap seseorang mengenai TOSS TB menjadi lebih baik.

\section{Pengaruh Rata-Rata Tingkat Pengetahuan TOSS TB Masyarakat Antara Kelompok leaflet dan Video}

Berdasarkan hasil uji statistik dengan menggunakan uji Kruskal Wallis menunjukkan nilai $\mathrm{p}$ values $=0,000(\mathrm{p}$ value $<0,05)$ yang berarti terdapat pengaruh yang signifikan antara selisih tingkat pengetahuan TOSS TB masyarakat antara sebelum dengan sesudah pada kedua kelompok. Pada hasil penelitian ini dapat dilihat bahwa selisih rata-rata pengetahuan pada kelompok video lebih tinggi dari pada dua kelompok lainnya.

Karynina Danti Putri 
Hasil penelitian ini sejalan dengan penelitian yang dilakukan oleh Hanissa (2018) bahwa skor pengetahuan dengan menggunakan video lebih tinggi dari pada menggunakan leaflet. ${ }^{35}$

Berdasarkan penelitian yang telah dilakukan oleh peneliti dapat diketahui bawa adanya perubahan pengetahuan TOSS TB pada masyarakat setelah diberikan intervensi dengan menggunakan leaflet dan video. Hal ini sesuai dengan teori oleh Agus,dkk (2013) yang menyatakan bahwa pengetahuan seseorang akan dipengaruhi sesuai dengan banyaknya infomasi yang diterima. Informasi merupakan sebuah metode dalam mengumpulkan, mengumumkan, menyebarkan dan menganalis sebuah topik dengan tujuan tertentu. ${ }^{30}$ Dalam menyampaikan informasi tersebut salah satunya dengan menggunakan media massa, yang mana pada penelitian ini media yang digunakan adalah leaflet dan media video.

\section{Pengaruh Rata-Rata Sikap TOSS TB Masyarakat Antara Kelompok leaflet dan Video}

Berdasarkan hasil uji statistik dengan menggunakan uji Kruskal Wallis menunjukkan nilai $\mathrm{p}$ values $=0,000$ ( $\mathrm{p}$ value $<0,05)$ yang berarti terdapat pengaruh yang signifikan antara selisih tingkat sikap TOSS TB masyarakat antara sebelum dengan sesudah pada kedua kelompok. Pada hasil penelitian ini dapat dilihat bahwa selisih rata-rata sikap pada kelompok video lebih tinggi dari pada dua kelompok lainnya. Hasil penelitian ini sejalan dengan penelitian yang dilakukan oleh Eka (2016) terdapatnya perubahan sikap lebih besar ketika menggunakan video bila dibandingkan dengan leaflet karena nilai selisih rata-rata yang berbeda jauh. ${ }^{36}$

Teori yang disampaikan oleh Azwar (2011) bahwa dalam melancarkan tercapainya suatu informasi diperlukan media yang mampu menimbulkan opini-opini masyarakat sehingga akan memengaruhi sikap seseorang. ${ }^{25}$ Akhir dari tingkatan sikap yang diharapkan adalah adanya timbul rasa bertanggung jawab, dimana sesorang mampu menanggung risiko dari keyakinan yang telah dilakukan. ${ }^{19}$ Perubahan sikap TOSS TB masyarakat yang positif tidak lepas dari peranan media leaflet dan video sebagai media edukasi kesehatan. Bila semakin banyak panca indra yang digunakan dalam menerima suatu informasi maka akan semakin jelas dan banyak pengetahuan yang diperoleh yang nantinya akan memengaruhi sikap seseorang.

\section{Simpulan}

Berdasarkan hasil penelitian ini didapatkan kesimpulan bahwa terdapat pengaruh terhadap tingkat pengetahuan dan sikap antara sebelum dan sesudah diberikan intervensi menggunakan media leaflet dan video. Terdapat perubahan ratarata tingkat pengetahuan dan sikap TOSS TB antara kelompok leaflet dengan video dimana kelompok video merupakan kelompok dengan perubahan rata-rata pengetahuan dan sikap TOSS TB yang paling besar. Sehingga kelompok video merupakan kelompok yang paling memberi pengaruh terhadap tingkat pengetahuan dan sikap mengenai TOSS TB terhadap masyarakat. Maka dari itu, masyarakat diharapkan setelah mendapatkan promosi kesehatan mengenai TOSS TB dapat lebih menambah wawasan pengetahuan dan sikapnya. Serta disarankan untuk memberikan promosi kesehatan mengenai TOSS TB yang lebih efektif dan menarik salah satunya dengan menggunakan video.

\section{Ucapan Terima Kasih}

Ucapan terima kasih penulis sampaikan kepada semua pihak yang telah turut membantu hingga selesainya penelitian ini.

\section{Daftar Pustaka}

1. Tiraihati WZ. Analisis promosi kesehatan berdasarkan ottawa charter di RS Onkologi Surabaya. Jurnal Promkes. 2017; 5(1): 1-11.

2. Heri D.J. Maulana. Promosi kesehatan. Jakarta: EGC; 2013.

3. Adam A, Wintoni E. Pengaruh media promosi kesehatan terhadap perilaku kesehatan pada remaja pelajar kelas XI di SMA Negeri 1 Pangkajene tahun 2015. Med Kom Kes FKM UPRI Makassar. 2016; 81: 19.

4. Agustini A. Promosi kesehatan. Jakarta: EGC; 2013.

5. Arsyad, Azhar. Media Pembelajaran. Jakarta: PT Raja Grafindo Persada; 2013.

6. Damayanti R, Shaluhiyah Z, Cahyo K. Peningkatan pengetahuan dan sikap ibu tentang phbs tatanan rumah tangga (ASI Eksklusif) di Kabupaten Sambas melalui media leaflet berbahasa daerah. J Promkes Ind. 2017; 12(1): 1-12.

7. Saleh RYR, Arya IFD, Afriandi I. Film yang efektif sebagai media promosi kesehatan bagi masyarakat. JSK. 2016; 2(2): 70-8.

8. Leonita E, Jalinus N. Peran media sosial dalam upaya promosi kesehatan. Jurnal INVOTEK. 2018; 18(2): 2534. 
9. World Health Organization. Global tuberculosis report 2019. Geneva. 2019.

10. Dinas Kesehatan Provinsi Sumatera Barat. Profil Dinas Kesehatan tahun 2018. Padang. 2018.

11. Dinas Kesehatan Kota Padang. Profil Kesehatan Kota Padang tahun 2018. Padang. 2018.

12. Badan Pusat Statistik Kota Padang. Distribusi dan kepadatan penduduk menurut kecamatan di Kota Padang, 2016-2018. https://padangkota.bps.go.id /dynamictable/2017/07/11/129/distribusi-dan-kepa datan-penduduk-menurut-kecamatan-di-kota-padang2016---2018.html - Diakses 22 November 2019.

13. Rakhmawati W. Efektivitas penggunaan media leaflet dan video untuk meningkatkan pengetahuan pemberian makanan pendamping air susu (MP ASI) di Desa Kenep Kecamatan Sukoharjo (Skripsi). Surakarta : Universitas Muhammadiyah Surakarta; 2018.

14. Sari NP, Rachmawati AS. Pendidikan kesehatan tuberkulosis "TOSS TB (temukan obati sampai sembuh)". Jurnal Abdimas Umtas. 2019; 21: 103-7.

15. Kementrian Kesehatan Republik Indonesia. Peraturan Mentri Kesehatan Republik Indonesia nomor 67. Jakarta: Kemenkes RI; 2016.

16. Sumiyati, Hastuti P, Widiasturi A. Efektifitas penyuluhan kesehatan terhadap pengetahuan dan sikap ibu balita tentang TB paru pada anak di Kabupaten Banyumas. Jurnal Poltekkes smg. 2018; 14(1): 7-13.

17. Notoatmodjo S Ilmu Perilaku Kesehatan. Jakarta: Rineka Cipta; 2014: 23-38.

18. Nataprawira HMN,dkk. Pengaruh intervensi media poster dan selebaran terhadap pengetahuan, sikap, dan perilaku pelajar pesantren Kabupaten Karawangan mengenai tuberkulosis. Jurnal Unpad. 2018; 16(1): 1-6.

19. Notoatmodjo S. Promosi kesehatan teori dan aplikasi. Jakarta : Rineka Cipta; 2010.

20. Djannah SN, Suryani D, Purwati A. Hubungan tingkat pengetahuan dan sikap dengan perilaku pencegahan penularan TBC pada mahasiswa di asrama Manokwari Sleman Yogyakarta. KES MAS. 2009; 3(3): 162-232.

21. Purnama AP. Efektivitas penggunaan media video dan media leaflet terhadap perubahan pengetahuan dan sikap siswa tentang bahaya napza di SMP Negeri 3 Mojosongo Boyolali. Surakarta: Universitas Muhammadiyah Surakarta; 2013.

22. Notoatmodjo S. Promosi kesehatan dan perilaku kesehatan. Jakarta: Rineka Cipta; 2012: p.16-24.

23. Kholid A. Promosi kesehatan dengan pendekatan teori perilaku, media dan aplikasinya. Depok: Raja Grafindo Persada; 2017.

24. Rakhmawati D, Haidah N, Suprijandani. Pengaruh penggunaan media leaflet dengan video tentang pengetahuan dan sikap siswa materi makanan jajanan. Gema Kesehatan Lingkungan. 2018; 16(1): 300-8.

25. Azwar S. Sikap manusia teori dan pengukurannya. Yogyakarta: Pustaka Pelajar; 2011.

26. Syamsiyah N. Pengaruh media leaflet terhadap perubahan pengetahuan dan intensi Asi eksklusif pada ibu hamil di Puskesman Kecamatan Pesanggarahan Jakarta Selatan Tahun 2013 (Skripsi). Jakarta : Universitas Islam Negeri Syarif Hidayatullah; 2013.

27. Putri ASA. Pengaruh pendidikan kesehatan dengan media video terhadap peningkatan pengetahuan dan sikap terhadap ASI eksklusif pada ibu hamil di wilayah kerja Puskesmas Umbulharjo I tahun 2019 (Skripsi). Yogyakarta: Politeknik Kesehatan Kementerian Kesehatan Yogyakarta; 2019.
28. Susilo R. Pendidikan kesehatan dalam keperawatan. Yogyakarta : Nuha Medika; 2011.

29. Guswir PP. Pengaruh penyuluhan menggunakan leaflet dan video terhadap perubahan pengetahuan anemia pada remaja putri untuk pencegahan anemia di SMKN 3 Padang tahun 2018 (Skripsi). Padang: Universitas Andalas; 2018.

30. Agus, Riyanto, Budiman. Kapita Selekta Kuesioner Pengetahuan dan Sikap Dalam Penelitian Kesehatan. Jakarta: Salemba Medika; 2013.

31. Pulungan SS. Pengaruh media poster kalender dan leaflet terhadap pengetahuan dan sikap pasien TB paru dalam menjaga kelangsungan pengobatan penyakit TB paru di Puskesmas Terjun Kota Medan tahun 2015 (Skripsi). Medan: Universitas Sumatera Utara; 2015.

32. Lestari $Y$, Nurhaeni N, Hayati H. Penerapan mobile video efektif meningkatkan pengetahuan dan sikap ibu dalam menurunkan lama diare balita di wilayah Puskesmas Kedaton Bandar Lampung. Jurnal Kep Ind. 2018; 21(1): 34-42.

33. Media Y. Pengetahuan, sikap, dan perilaku masyarakat tentang penyakit tuberkulosis (TB) paru di Kecamatan Sungai Tarab, Kabupaten Tanah Datar Provinsi Sumatera Barat. Media Litbang Kesehatan. 2011; 21(2): 82-8.

34. Syukaisih, dkk. Efektivitas promosi kesehatan dengan media leaflet dan video terhadap pengetahuan dan sikap masyarakat miskin tentang merokok. Jurnal Penelitian Kesehatan Suara Flores. 2018; 9(4): 248257.

35. Ma'mun HM. Efektivitas Penggunaan media leaflet dan video terhadap pengetahuan pedoman gizi seimbang pada siswa SMP negeri 5 Yogyakarta (Skripsi). Yogyakarta: Politeknik Kesehatan Kementerian Kesehatan Yogyakarta; 2018.

36. Tarigan ER. Efektivitas promosi kesehatan dengan media leaflet dan media video terhadap pengetahuan dan sikap remaja tentang HIV/AIDS di SMA Negeri 1 Berastagi tahun 2016. Medan: Universitas Sumatera Utara; 2016.

37. Pulungan SS. Pengaruh media poster kalender dan leaflet terhadap pengetahuan dan sikap pasien tb paru dalam menjaga kelangsungan pengobatan penyakit TB paru di Puskesmas Terjun Kota Medan tahun 2015 (Skripsi). Medan : Universitas Sumatera Utara; 2015.

38. Kanoralma K, Alow GBH. Efektifitas metode ceramah dan leaflet dalam upaya meningkatkan perilaku penderita tuberkulosis paru tentang pencegahan penularan penyakit TB paru di Puskesmas Tuminting Kota Manado (Skripsi). Manado : Poltekkes Kemenkes Manado; 2017. 